\title{
3. Efficiency of Resource Mobilisation by Financial Intermediaries
}

In practice, the benefit/cost ratio of a country's financial intermediaries cannot be measured. There is no direct indicator of total benefits. Therefore, various indirect methods of evaluating efficiency must be used. Ceteris parfbus, unit resource costs of intermediation between savers and investors would be associated negatively with efficiency. However, it is crucial here to measure resource costs of transferring funds from original savers to final investors. Unit resource costs per financial intermediary may be very misleading if, as is the case in India, for example, there is much financial layering, i.e., one financlal intermediary borrowing from another financial intermediary which, in turn, borrows from yet another. In this case, unit resource costs of each financial Intermediary must be summed to produce the total intermediation cost between savers and investors.

Taking financial layering into account, costs of financlal intermediation might be measured at the micro level by assessing the resource costs assoclated with lending for new investment from an increase in avallable funds, i.e., from saving. In practice, total operating costs - wages, depreclation, intermediate input costs, e.g., computer expenses, advertising, etc. - as a percentage of total earning assets may serve as a reasonable proxy. Ceteris paribus, the lower this percentage, the smaller will be the spread between net returns to savers and gross costs to investors. As shown in the previous section, higher net returns to savers and lower gross costs to investors may increase both saving and investment and, hence, the rate of economic growth. 
Operating costs as a percentage of total earning assets can be calculated from balance sheets and income statements usually published annually by all financial intermediaries. Time series data for one particular country may indicate efficlency trends. For example, the following operating costs were calculated for all commercial banks in Turkey: 1967,6.56 per cent; 1972, 7.43 per cent; 1977, 8.54 per cent. The comparable 1976 figure for all insured banks in the U.S. was 3.39 per cent. Operating costs of Turkish banks in 1977 were two and a half times those of American banks in 1976.

The explanation for the high and rising bank operating costs in Turkey compared to the U.S. lies in: (a) interest rate ceflings; (b) an oligopolistic and cartelised industry; (c) accelerating inflation; and (d) high and rising reserve requirements. Deposit rates of interest administratively fixed below their market equilibrium levels cause banks to substitute nonprice for price competition. In Turkey, there has been large bank expenditure on advertising and opening new bank branches. As inflation accelerated in the 1970 s (from under 10 per cent in every year between 1960 and 1970 to about 100 per cent in 1980), the gap between the free competitive market equilibrium deposit rate and the fixed ceiling widened. The result was even higher levels of expenditure on nonprice competition. Expenditure by depository institutions on nonprice competition has nowhere been valued by depositors at par with interest payments. The evidence comes from money demand estimates which invariably show that real money demand is associated positively with the real deposit rate of interest, 1.e., the nominal deposit rate minus expected inflation. Money is always defined here broadly to include savings, time and post office deposits, as well as currency in circulation and sight deposits. 
Nonprice competition incurs resource costs while price competition in the form of higiner deposit rates does not. Interest is a transfer payment and involves no resource cost. This distinction would not matter from the welfare standpoint were the resource costs of nonprice competition valued at par by depositors. Since, clearly, they are not, there is resource misallocation when depository institutions are forced to substitute nonprice for price competition.

Deposit rate ceilings tend to encourage and condone bank cartels. Overt banking cartels for interest rate setting exist in the Bahamas, Hong Kong and Seychelles, among the sample countries. Cartels tend to raise operating resource costs, so reducing the efficiency of financial intermediation:

\begin{abstract}
Many observers have remarked that the gap between rates on loans and rates on deposits is excessive in Turkey compared to other countries. High costs would appear to absorb a large part of this gap. Why are costs high? One simple answer is that costs are high because the gap is wide. As both loan and leposit rates are flxed, perfect competition does not exist. Non-frice competition in the form of massive advertising expenditure, impressive buildings, etc., takes place. Furthermore, there is no incentive to be efficient. To exhibit large profits is asking the authorities to step in and reduce the gap. This is the kind of market situation in which tacit collusion to maintain high costs and to keep profits within certain limits would flourish. [Fry (1972, p.127)]
\end{abstract}

Accelerating inflation combined with fixed or sticky nominal deposit rates of interest reduces real money demand and, hence, the real volume of resources at the disposal of the financial intermediaries. The nominal volume of deposits fails to increase in step with nominal GNP, perhaps not even in step with inflation itself, as inflation accelerates. Bank operating costs, on the other hand, do tend to rise in step with nominal GNP. Hence, as a percentage of earning assets, operating costs increase. 
A dramatic inflation-induced rise in bank operating costs occurred in Brazil as inflation there rose from 13 per cent in 1952 to 41 per cent in 1966. Bank operating expenses as a percentage of bank loans outstanding increased on average from 6 per cent in 1952 to 24 per cent in 1966 [Christoffersen (1968, pp.9a and 18a)]. The explanation here is identical to that provided above for the Turkish case.

Higher reserve requirements raise bank operating costs. Ignoring bank capital and excess reserves, earning assets equal deposit liabilities when required reserves are zero. Suppose resource costs of maintaining deposits are 2 per cent of total deposits and costs of servicing the asset portfolio 3 per cent. In this case, the overall bank operating cost ratio is simply 5 per cent. Now consider what happens when a required reserve ratio of 50 per cent is imposed. For the same deposit volume, the earning assets are halved. The calculated overall bank operating cost ratio is now 3 per cent for earning assets, but resource costs for maintaining a volume of deposits twice the size of the earning asset portfolio are 4 per cent of earning assets. Hence, the overall bank operating cost ratio is now 7 per cent.

In addition to operating resource costs which drive a wedge between financial intermediaries' lending and borrowing rates, there are two additional factors reserve requirements and taxes - to be considered. In fact, required reserves are themselves a form of taxation on financial intermediation. Suppose earning assets yield an average return of 12 per cent. Again ignoring excess reserves and cap1tal, financial intermediaries could just offer 7 per cent on deposit liabilities and break even, given resource costs of 2 per cent for deposits and 3 per cent for earning assets, as in the example above, when the required reserve ratio is zero. 
Now introduce a 50 per cent reserve requirement. The resource costs rise to 7 per cent of earning assets and the net yield on earning assets of 5 per cent has to be spread over deposits twice the size of these assets. Hence, the average deposit rate is reduced from 7 to $2 \frac{1}{2}$ per cent. The spread between lendIng and borrowing rates has widened from 5 per cent (the operating cost ratio) with zero required reserves to $9 \frac{1}{2}$ per cent. The 50 per cent reserve requirement effectively imposes a tax on deposits of $2 \frac{1}{2}$ per cent.

The reserve requirement tax increases as inflation accelerates. Suppose Inflation rises from zero to 10 per cent and earning assets now yield an average return of 22 per cent (12 per cent plus the 10 per cent inflation adjustment). Ceteris paribus, financial intermediaries will be able to offer a maximum deposit rate of $7 \frac{1}{2}$ per cent -22 minus 7 , the result divided by 2 . The 50 per cent reserve requirement now imposes an effective tax on deposits of $7 \frac{1}{2}$ per cent. And it has reduced the real return on deposits from $+2 \frac{1}{2}$ per cent to $-2 \frac{1}{2}$ per cent. Naturally, savers are deterred by the substantial decline in their real return. Real money demand and, hence, the real volume of financial intermediation will fall. This, in turn, raises the operating resource cost ratio, since financial Intermediation is subject to economies of scale.

Conventional taxes - interest withholding taxes, stamp duties, transactions taxes, value added taxes, profit taxes, licence fees, etc. - all widen the competitive spread between financial intermediaries' borrowing and lending rates. They, therefore, have exactly the same effect on the real volume of financial intermediation, saving and investment as do higher operating resource costs.

If one of the objectives of an economic development plan is to encourage domestic resource mobilisation, then discriminatory taxes - conventional as well 
as reserve requirements - on financial intermediation should be removed. At the same time, bank cartels must be destroyed and financial intermediaries made to behave competitively. The optimal competitive solution might have to be forced upon some of the sample countries' cartelised and/or oligopolistic financial systems by fixing minimum deposit rates of interest and obliging depository institutions to satisfy all deposit demand at these rates. This would be the only control needed to produce the competitive result, provided loan demand were elastic at rates above the competitive loan rates of interest [Fry (1980b, p.543)]. Minimum deposit rates are clearly preferred to licence fees as a means of tapping monopoly profit. Barbados does actually set minimum deposit rates.

The easiest way to establish and then maintain a real deposit rate approxImating the competitive rate is deposit indexation. Depository institutions would be directed to adjust nominal deposit values by the change in an appropriate Index at regular intervals. For most of the sample countries, the best index might be calculated from trade-weighted average government bond yields in industrialised countries adjusted for any change in the value of the domestic currency vis-a-vis this currency basket. For example, the exchange rate might start at Rs 5 to $B 1$, where Rs represents the domestic currency and $B$ is the trade-weighted currency basket. Over the subsequent month, foreign government bond yields average 0.75 per cent (as a monthly rate). In this case, the index moves from 100.00 to 100.75. If the exchange rate had depreciated from Rs 5 to B1 to Rs 5.10 to B1, then the index becomes 102.765 , i.e., 5.10 divided by 5 , the result multiplied by 100.75 .

Now financial intermediaries would adjust all deposit values by the change in the index every month. A balance of Rs 10,000 is adjusted automatically to 
Rs 10,276.50. Any nominal interest offered, say, on longer-term deposits would be paid on the adjusted deposit value. Depositors know in advance that they will be compensated for subsequent price changes. Hence, their own expectations regarding the future inflation rate are now irrelevant to their deposit holding decisions. And the real deposit rate equals whatever nominal rate is paid on the adjusted deposit value plus the trade-weighted average real government bond yield abroad. The latter has tended to remain remarkably stable in most industrial countries for most of this century.

Efficiency of financial intermediation is affected positively by economy size for two reasons. First, a large economy can support a large financial intermediary and there are economies of scale to financial intermediation [Baltensperger (1972)]. Second, there is more potential for competition in a larger than in a smaller economy. Whether or not that potential is realised depends on the legal and regulatory environment in which the financial intermediaries operate. All one can conclude here is that it is probably impossible under any circumstances for the Maldives to attain as great efficiency of financial intermediation as, say, Hong Kong or Singapore.

Apart from constraints imposed by economy size, however, monetary authorities can have considerable influence over financial intermediaries' operating efficlency. No matter how small the economy, competitive conditions can be simulated through minimum deposit rates. All other interest rate regulations can be dismantled.

Domestic inflation in all the sample countries is determined by exchange rate policy. In today's inflationary world, gradual appreciation of the domestic currency vis-a-vis a trade-weighted currency basket is needed to ensure price 
stability. Papua New Guinea, Singapore, the Solomon Islands and Western Samoa have all opted for below-average inflation rates over the past quinquennium by means of domestic currency appreciation. Aside from other benefits of price stability, there is, ceteris paribus, greater efficiency of financial intermediation.

Reserve requirements do not constitute an instrument of monetary control In any of the sample countries. The nominal money supply is an endogenous variable determined $\underline{\text { inter }}$ alia by exchange rate policy. However, reserve requirements can and do extract seigniorage from financial intermediaries subject to them. They are a discriminatory tax which increases the spread between financial intermediaries" lending and borrowing rates. In turn, this greater spread reduces the aggregate size of the financial sector and so may raise operating resource cost ratios. In addition, of course, reserve requirements ensure a divergence between private and social or resource costs and, hence, produce a suboptimal level of financial intermediation. If required reserves are deemed essential on prudential grounds, they should receive a competitive market return [Fry $(1979 a$, p.641)].

The Maldives and the Solomon Islands have no regulations pertaining to financial intermediaries' asset portfolios. Hong Kong and Papua New Guiner set no required reserve ratios but do impose minimum liquid asset ratios. In effect, this is almost the same as paying a competitive interest rate on required reserves. Liquid assets are defined broadly in Hong Kong and the regulation has several loopholes which render it ineffective, while financial intermediaries in Papua New Guinea typically hold liquid assets far in excess of the requirements. 
Of the remaining countries in the sample, all of which do impose cash reserve requirements on their financial intermediaries, only Fiji pays any interest - $3 \frac{1}{2}$ per cent - on required but not excess reserves held on deposit with the Central Monetary Authority. However, the reserve requirement in Western Samoa imposes no net tax on the financial intermediaries as a group because the reserves deposited with the Monetary Board are redeposited back with one of the two commercial banks. Hence, its sole impact is to redistribute income from the newer bank - the Pacific Commercial Bank - to the commercial bank which actually issues Western Samoa's currency - the Bank of Western Samoa, in which the government has 50 per cent ownership.

The remaining five countries in the sample could raise the efficiency as well as the quantity of financial intermediation from suboptimal towards optimal levels by paying a market rate of interest on required reserves, substituting a liberally-defined liquid asset ratio for the required reserve ratio, or simply abolishing reserve requirements altogether.

Only intramarginal taxes tapping purely consumer or producer surpluses, e.g., a poll tax, produce no economic distortions. And it turns out that several of the sample countries effectively impose intramarginal taxes on money holders. Table 2 gives the current structure of deposit rates of interest and the average inflation rate as measured by the consumer price index over the period 1978-1980 for eight of the sample countries. In only one of these countries - Singapore were deposit rates determined competitively in a free market. And in only one of these countries - Singapore - were real deposit rates of interest positive on average over the period 1978-1980. All real deposit rates were negative in the seven other countries on average over this period. 
TABLE 2

Deposit Rates of Interest and Inflation

(Per Cent)

\begin{tabular}{|c|c|c|c|c|c|c|}
\hline & & & & & & \\
\hline (Date Introduced) & Savings & $3 \mathrm{mth}$ & $6 \mathrm{mth}$ & $12 \mathrm{mth}$ & $2-3$ yr & $(1978-80)$ \\
\hline $\begin{array}{l}\text { Bahamas } \\
\text { (1980 IV) }\end{array}$ & 6.39 & 7.74 & 7.98 & 8.11 & 8.56 & 9.1 \\
\hline $\begin{array}{l}\text { Barbados } \\
(3 / 1980)\end{array}$ & $3.0-5.0$ & $3.5-4.5$ & $3.8-5.0$ & $4.0-5.5$ & - & 13.5 \\
\hline $\begin{array}{l}\text { Fij } 1 \\
\quad(9 / 1980)\end{array}$ & 4.5 & 5.5 & 6.25 & 7.0 & $8.0-8.5$ & 9.2 \\
\hline $\begin{array}{l}\text { Papua New Guinea } \\
\qquad(12 / 1979)\end{array}$ & 3.75 & $4.75-7.2$ & - & $5.5-7.5$ & - & 7.6 \\
\hline $\begin{array}{r}\text { Seychelles } \\
(5 / 1980)\end{array}$ & $6.5-8.0$ & 8.0 & 8,5 & 9.0 & 10.0 & 12.6 \\
\hline $\begin{array}{l}\text { Singapore } \\
(3 / 1980)\end{array}$ & 7.52 & 8.79 & 8.80 & 8.56 & - & 5.8 \\
\hline $\begin{array}{l}\text { Solomon Islands } \\
(9 / 1980)\end{array}$ & 4.0 & $5.75-6.0$ & 6.5 & - & - & 9.1 \\
\hline $\begin{array}{c}\text { Western Samoa } \\
(6 / 1979)\end{array}$ & 4.0 & 6.5 & 7.0 & 8.0 & 8.5 & 13.8 \\
\hline
\end{tabular}

Source: Central bank publications and International Financial Statistics 
Of significance here is the fact that the term structures of deposit rates in Fiji, Papua New Guinea, Seychelles and Western Samoa are steeply rising. This indicates neither strong liquidity preference nor high marginal rates of time preference - these structures are imposed solely from the supply side. What they do approximate, however, is a monopolist's profit-maximising strategy through product differentiation [Fry (1981c)].

The problem can be viewed as one of minimising the cost of generating a given real money demand [Fry (1978c)]. Given the inflation rate and the real money demand target, interest costs will be minimised by paying zero or low nominal rates on sight and short-term time deposits, for which there are no close substitutes, and higher rates on longer-term deposits, for which closer substitutes in the form of tangible inflation hedges do exist. To stabilise the aggregate real money demand in the face of volatile inflation, the nominal rates of longer-term time deposits must be adjusted continucusly in stap with changes in inflationary expectations. In other words, the real deposit rate on long-term deposits has to be held constant. Therefore, the term structure has to be tilted more, the higher is the expected rate of inflation.

Whether the appropriate real rate on long-term deposits is negative, positive or zero depends on the volume of real money demand to be generated. In a growing or potentially growing economy, the basic objective of accelerating economic growth would necessitate positive real long-term time deposit rates in order to maximise the real supply of domestic credit, one of the main assets backing deposit 1iabilitles of the financial intermediaries. Positive real long-term time deposit rates also deter socially inefficient currency substitution and excessive foreign borrowing, both of which may well involve unnecessary resource costs borne entirely by the small island developing economy [Fry (1980d, pp.888-891)]. 
From another viewpoint, a greater inflation tax is levied on current and short-term deposits, for which there are no close substitutes, while a smaller tax is extracted from deposits for which closer substitutes do exist. Monopol1stic product differentiation is designed to tap consumer surplus, in this case from savers. The tax is used in some of the sample countries as one source of credit subsidy for priority sectors. It is also absorbed in high administrative costs of the uncompetitive financial sectors found in all these countries, with the exception of Singapore.

Governments of most of the sample countries appear to behave as if they were subject to two conflicting objectives. On the one hand, they are anxious to mobilise domestic resources by offering attractive returns to savers. On the other hand, they wish to finance their own sometimes considerable borrowing requirements as cheaply as possible. Furthermore, some of these governments excluding those of Bahamas, Hong Kong, Maldives and Singapore - clearly believe that priority groups, sectors and regions need cheap credit.

These objectives may indeed conflict when the subsidies for government and other priority borrowers are paid by deposit holders. A proportional tax on all deposits to be spread proportionally among borrowers would have no effect at all, provided that interest rates were adjusted upwards by exactly the amount of the tax/subsidy; free market interest rates would make this adjustment automatically. Were rates not adjusted, the quantity of deposits demanded, 1.e., lending, would decline.

The two objectives need not conflict, however, were the tax on deposit holders levied as a poll tax or in the form of any alternative intramarginal tax which tapped only consumer surplus. The monopolistic price discrimination in 
terms of the present structures of deposit yields in Fiji, Papua New Guinea, Seychelles and Western Samoa do seem, In princlple, capable of tapping consumer surplus without reducing aggregate real money demand. Unfortunately, the rigidity of the structure of nominal institutional interest rates produces money demand fluctuations pari passu with changes in inflationary expectations. Indexation of long-term time deposits to a price index would introduce the necessary flexibility in effective nominal rates to allow consumer surplus to be tapped without reducing real money demand in the face of rising inflationary expectations.

Concern over the efficiency of financial intermediation would barely be warranted were saving completely interest-inelastic. If, however, saving is responsive to the net real yield on indirect claims, then reducing the spread between financial intermediaries' lending and borrowing rates w1ll increase saving, investment and the rate of economic growth.

01 son and Bailey $(1981, \mathrm{p} .1)$ show that

[t]he case for positive time preference is absolutely compeling, unless there is an infinite time horizon with the expectation of unending technological advance combined with what we call "drastically diminishing marginal utility." This finding holds both in the positive and normative senses. A corollary is that savings are interest elastic. [Italics added]

The present author has conducted empirical tests on a number of developing countries. In all cases, the results are consistent with the hypothesis that national saving rates are affected positively and significantly by the real deposit rate of interest [Abe et al. (1977); Fry (1976a, pp.61-62; 1978d; 1979b; 1980a; 1981a; 1981b; 1982); Fry and Farhi (1979, p.197); Fry and Mason (1981)]. 